\title{
From Catholic Social Thought to Catholic Economics and Back: António Almodovar's interest into an unexpected subject
}

\author{
Pedro Teixeira ${ }^{1}$
}

Received: 31/05/2017 / Accepted: 31/05/2017

\begin{abstract}
In the last decade of his career before his untimely death, António Almodovar's research was very much dominated by an interest in catholic economic thought, apparently an unexpected development in his career. However, it fitted his broader approach to the history of economics, which presented a strong emphasis on the dissemination of economic ideas as in his previous work on the institutionalization of political economy or in the parliamentary debates or in textbooks. His interest in the overlap between religious and economic thought also corresponded to a reflection about the boundaries of economic thought and their evolution.
\end{abstract}

Keywords: António Almodovar, Portuguese economic thought

JEL Classification: B2, B3

[es] Del Pensamiento Económico Católico a la Economía Católica y vuelta: el interés de António Almodovar en un tema inesperado

Resumen. En la última década de su carrera antes de su inesperada muerte, la investigación de António Almodovar estuvo dominada por su interés en el pensamiento económico católico, aparentemente una derivación inesperada en su trayectoria. Sin embargo, encajaba en su enfoque más amplio de la historia de economía, que enfatizaba la diseminación de ideas económicas como en su trabajo anterior sobre la institucionalización de economía política o de los debates parlamentarios o manuales. Su interés por la relación entre el pensamiento religioso y económico también responde a una reflexión sobre las fronteras del pensamiento económico y su evolución.

Palabras clave: António Almodovar, pensamiento económico portugués

Clasificación JEL: B2, B3

\section{António Almodovar's interest into an unexpected subject}

In the last decade or so of his career before his untimely death, António Almodovar's research was very much dominated by an interest in catholic economic thought. The interest of António Almodovar in catholic economic thought was apparently an unexpected development in his career, though it was rather coherent with his previous work and his approach to the history of economic thought. To a large extent, it fitted his broader approach to the history of economics, which presented a strong emphasis on the dissemination of economic ideas as in his previous work on the institutionalization of political economy or in the parliamentary debates or in textbooks. His interest in the overlap between religious and economic thought also corresponded to a reflection about the boundaries of economic thought and their evolution. Thus, he considered that a restrictive definition of boundaries in retrospect would impoverish our historical understanding about who had contributed to the production of economic ideas and discourses in the past. Moreover, it also led us to a much more fluid analysis of the interplay between "economists" and other individuals that had contributed to shape economic debates in the past.

\footnotetext{
University of Porto.

pedrotx@fep.up.pt

orcid.org/0000-0002-7128-8238
} 
This interest in catholic economic thought also faced some perplexities among colleagues and historians of economics. On the one hand, because catholic thought is largely ignored in HET, especially after late Scholastics and the School of Salamanca, and even that tends to be known mainly by experts in pre-classical political economy. On the other hand, because of the evolution of religious studies in Catholic countries (especially in Southern European). These have been dominated by theological approaches, often associated with a discourse with hints of proselytism or legimization of certain aspects of the social, political, and economic order. By contrast, Social sciences have largely ignored catholic thought, since this was not considered as a relevant topic for most economists, sociologists or political scientists. This presents a striking contrast with other Christian traditions, namely with protestant countries, where there is a body of reflection about the historical relevance of Protestantism in economic thought.

One of his first concerns referred to conceptual issues, namely if there was such a thing as catholic economics and how to differentiate it from catholic social thought (Teixeira and Almodovar, 2008). In fact, his research aimed at distinguishing different layers in catholic thought and to emphasise that some were more relevant than others to the history of economic thought, notably given its economic content and its degree of engagement in economic debates. The other related concern was to what extent it was appropriate to refer to a School of economic thought and what defined it. In his research, he would also attempt to identify different periods that could help us to understand the evolution of the school.

To a large extent he was particularly interested in the period previous to the publication of Pope Leo XII encyclical Rerum Novarum (1891). This is significant, as most authors focusing on catholic social thought tend to focus on its impact and the developments thereafter. In fact, his research, nurtured by a deep and comprehensive knowledge of political economy in the nineteenth century, would identify a very rich picture of catholic political economists in the decades prior to the aforementioned encyclical (Almodovar and Teixeira, 2012). This would include major names like Villeneuve-Bargemont, but also the groups emerging around the Catholic University of Louvain (Charles de Coux, Charles Périn, Vic- tor Brants, and Maurice Defourny) or around the journal Civiltà Cattolica like Taparelli D'Azeglio; Valentino Steccanella; Matteo Liberatore and Angelo Brucculieri. António Almodovar tried to substantiate the claim that they were building an analytical and doctrinal body of catholic economics that was part of Political Economy. Contrary to the view of many, they did not reject the relevance and legitimacy of Economics, but were willing to forge an alternative school within that strand of knowledge infused by catholic principles and values. Thus, the publication of the encyclical could and should be understood has being nurtured by several decades of economic reflection in several catholic circles, notably the ones identified above.

He certainly acknowledged the importance of Rerum Novarum, not the least by the visibility and legitimacy that it gave to that intellectual enterprise. Thus we would see a so-called golden period of catholic economic thought between its publication and the publication of Pius XI encyclical Quadragesimo Anno in 1931 (Almodovar and Teixeira, 2008). This vitality would be illustrated by the proliferation of textbooks and treatises, conference and congresses (Teixeira and Almodovar, 2005), or even by the growing willingness to define an alternative Economic System that would replace excessive liberalism and unchristian socialism, which would become increasingly connected to corporatism (Almodovar and Cardoso, 2005).

This golden period would give way to a post-war decline to which had contributed significantly the demise of Corporatism, tainted by association with authoritarian regimes like the one in Italy, and an evolution to an approach that tended to regard catholic economic thought more like a doctrine rather than a theory or a system. This was justified by the perspective that the views of the Church could not be subsumed into a disciplinary approach. Moreover, the changes in Economics, notably its increasing professionalization, formalization or emphasis on scientificity and positivism would make it more difficult for more normative and discursive approaches to attain certain influence in economic debates.

In his research about catholic economic thought António Almodovar tried to identify the major themes that characterized that school of economic thought, also pointing out to the evolution and changes within the school. 
Among the leading themes, we could identify the relevance of Christianism for Wealth, Stability, and Progress and those associated with the so-called Social Question, like those referring to labour conditions; child and female labour (family values); welfare and social support mechanisms; and the fair wage. Finally, there were also the themes linked to Social organization and the Common Good, like the ones referring to social bonds, solidarity, mutual obligations, and the responsibility associated with property and wealth. Linked to several ones was also the role of the State. His analysis of catholic economic thought also highlighted some tensions and differences among those authors. Namely, he tended to identify two major groups, one closer to a conservatist view and another to a more Reformist one. There were also differences when it referred to the weight attached to issues of authority/order vis-à-vis that of freedom.

Summing-up, António Almodovar's contributions to a much richer understanding of this important chapter in the history of political economy ranged from conceptual issues, providing a periodization, a conceptual framework for the understanding of that group of authors and the major themes and diversity within the School (Teixeira and Amaral, 2014). In the text that follows, António Almodovar presents an overview of this work, highlighting most of the aspects briefly presented in this text.

António Almodovar's interest on the topic apparently followed several days of discussions between António Almodovar and me, when I was preparing a paper to a conference in France on the economic content of papal encyclicals. The discussions reignited his interest that led to a joint paper (Teixeira and Almodovar, 2005). Several years before, then a young teaching assistant lured by his enthusiasm and knowledge on the history of economic thought, I had stimulated him to participate more frequently in academic conferences. In doing this, I have contributed to a certain extent in getting him increasingly active in international networks, despite his fear of flying (something that he acknowledged to me many years later[...]). As someone that is so much indebted to him, at personal and intellectual levels, I am very happy that my proverbial optimism and tendency to commit myself to too many things have led many more people to get to know the wonderful academic and person that he was and to have been part of such a fruitful and gratifying journey. His legacy will certainly endure, though this seems at times so little visà-vis the void that his physical disappearance has left in our lives. Certainly in mine.

\section{References}

Almodovar, António and Teixeira, Pedro. 2012. Catholic in its faith, catholic in its manner of conceiving science: French Catholic Political Economy in the 1830's. The European Journal of the History of Economic Thought, (19), 2, 197-225

Almodovar, António, and José Luís Cardoso. (2005). Corporatism and the Role of Government. In The Role of Government in the History of Economic Thought, History of Political Economy, Annual Supplement to volume 37, edited by Steven G. Medema and Peter Boettke. Durham, NC, Duke University Press, p. 333-354.

Almodovar, António and Teixeira, Pedro. 2008. The Ascent and Decline of Catholic Economic Thought 1830-1950s. History of Political Economy (40), Supplement, 62-87

Teixeira, Pedro, and Almodovar, António. 2005. Toute la lumière sur l'effroyable science: Le Marché dans la pensée catholique sociale et économique (1891-1931). In Histoire des représentations du marché, edited by Guy Bensimon. Paris, Michel Houdiard Éditeur, pp. 94-118

Teixeira, Pedro, and Almodovar, António. 2008. Catholic economic thought. In: The New Palgrave Dictionary of Economics, $2^{\text {nd }}$ Edition, Steven Durlauf and Lawrence Blume (eds.), London, Palgrave-Macmillan.

Teixeira, Pedro, and Almodovar, António. 2014. Economics and Theology in Europe from the 19th Century: From Early 19th Century's Christian Political Economy to Modern Catholic Social Doctrine. In Paul Oslington (ed.), The Oxford Handbook of Christianity and Economics. Oxford, Oxford University Press, 113-134. 